\section{Research Article}

(c) 2021 Ahmad et al. This is an open access article licensed under the Creative Commons Attribution-NonCommercial 4.o International License (https://creativecommons.org/licenses/by-nc/4.o/)

\title{
Investor Reaction to the Discovery of Accounting Fraud: The Period from the Discovery of the Fraud to the Completion of the Correction
}

\author{
Syed Raziuddin Ahmad ${ }^{1}$ \\ Nabil Ahmed Mareai Senan²
}

Ijaz Ali3

Kashif Ali ${ }^{4}$

Imran Ahmad Khan 5

\begin{abstract}
Asif Baig6
${ }^{1}$ Department of Accounting, Faculty of Business Studies, Arab Open University, Saudi Arabia ${ }^{2}$ Associate Professor, Department of Accounting, College of Business Administration, Prince Sattam bin Abdul Aziz University, Saudi Arabia; Administrative Science College, Albaydha University, Yemen ${ }^{3}$ Assistant Professor, College of Business and Management, Fahad Bin Sultan University, Tabuk, Saudi Arabia ${ }^{4}$ Ulster University, Birmingham, United Kingdom ${ }^{5}$ Researcher and Consultant, Creative Heads Consultants, India ${ }^{6}$ Assistant Professor, Jubail University College, Jubail Industrial City, Jubail, Saudi Arabia
\end{abstract}

DOI: https://doi.org/10.36941/ajis-2021-0163

\section{Abstract}

This paper examines the period from the discovery of accounting fraud to the completion of correction and examines the reaction of investors on the date of the first news release suggesting accounting manipulation, the date of the subsequent release of information related to the amount of profit correction that was not disclosed on the date of the first news release, and the date of the submission of the correction report. The verification results show that the stock price falls sharply on the day of the first news release and the day when the information about the amount of profit revision is disclosed, that when the amount of profit revision is large and it takes time to disclose information about the amount of profit revision, there is a rebound in the stock price on the day when the correction report is submitted because investors like the resolution of uncertainty, and that there is a relationship between the amount of profit revision and the size of stock price decline. However, when there is no information about the amount of correction on the first day of the news release, investors react uniformly, and the reaction to a large (small) amount of correction is underreaction (overreaction). These results indicate that investors were misled by the misstatements until the fraud was discovered and made decisions based on overestimates of future cash flows, so they suffered unexpected losses when the fraud was discovered, and during the period from the fraud discovery to the completion of correction.

Keywords: Fraud; Profit; Information; Correction; Investors; Disclosure 


\section{Introduction}

When investors learn of material misstatements in financial reports, they are likely to change their expectations about the value of the company and to rely on management and disclosed information in making investment decisions. Therefore, it is necessary to disclose such facts to investors promptly. Listed companies are required to immediately disclose the details of any "material fact concerning their operations, business, or assets, or concerning their listed share certificates, etc., that may significantly affect the investment decisions of investors" (BSE Listing Regulations, Rule 402, Item $2 x$ ). In the case of serious violations of laws and regulations or other improper or inappropriate actions, disclosure is required to be "prompt and accurate, from the stage of identification to the stage of implementation of measures to prevent a recurrence, in line with the need" (Indian Securities Exchange, 2016).

However, the judgment of the balance between promptness and accuracy of information disclosure varies from company to company. For example, the first report may be disclosed as soon as the signs are identified, or after the facts such as the outline and financial impact become clear. On the other hand, some companies go bankrupt or delist before submitting a correction report. In light of these circumstances, the uncertainty that investors face after the discovery of fraud is considered to be quite high. Of these uncertainties, at least those concerning the content of the correction should be resolved by the submission of the correction report after the audit.

Therefore, this paper examines the period from the discovery of the accounting fraud to the completion of the correction and examines the reaction of investors on the date of the first news release suggesting accounting manipulation, the date of the subsequent release of information related to the amount of profit correction that was not disclosed on the date of the first news release, and the date of the submission of the correction report.

We examined how investors reacted to the first news release, whether they reacted in anticipation of a profit correction that was unknown or unconfirmed at the time, whether they reacted in anticipation of the severity of the correction based on the availability of information about the correction on the first news release, and whether the effect of the correction on investors depended on the availability of information about the correction on the first news release. The same applies to the verification of the date of the subsequent report and the date of the filing of the correction report for the information related to the amount of profit correction.

As a result of the verification, it can be said that the stock price falls sharply on the day of the first news release and the day when the information about the amount of the profit revision is disclosed, that when the amount of the profit revision is large and it takes time to disclose the information about the amount of the profit revision, there is a rebound in the stock price on the day when the correction report is submitted because investors like the resolution of uncertainty, and that there is a relationship between the amount of the profit revision and the size of the stock price decline. However, when there is no information about the amount of the correction on the first day of the news, investors react uniformly, and the reaction to a large (small) amount of the correction is underreaction (overreaction). These results indicate that investors were misled by the misstatement until the discovery of the fraud and made decisions based on the overestimation of future cash flows, so they suffered unexpected losses when the fraud was discovered, and that they revised their expectations accordingly using the information (including the presence or absence of the information) about the amount of profit correction disclosed during the period from the discovery of the fraud to the completion of the correction, but that the stock price fluctuated wildly during the period because the information was noisy.

The structure of this paper is as follows. Section 2 summarizes the related previous studies and confirms the position of this paper. Section 3 presents the hypothesis. Section 4 clarifies the sample selection method and its basic characteristics, and Section 5 describes the validation model and results. Then, we perform additional verification and robustness testing in Section 6. Section 7 summarizes this paper and points out the contributions and limitations of this paper. 


\section{Previous Research}

The theme of this paper is to examine the reaction of investors on the date of the first news release suggesting accounting manipulation (date1), the date of the subsequent news release of information related to the amount of profit correction (MST) that was not disclosed on date1 (datez), and the date of the filing of the correction report (date3). Kinney and McDaniel (1989) is an early study related to this topic. Kinney and McDaniel (1989) found that stock prices of U.S. companies that corrected quarterly profits in the notes to their annual financial statements declined before the date of the audit report (before dateı) and that the decline in stock prices was greater for companies with deteriorating annual performance that overstated quarterly profits. This result indicates that investors do not react to datel, but they interpret it from the perspective of auditor's incentives, either because auditors, who know that stock prices are falling and earnings are deteriorating, have tightened their audits and discovered new misstatements, or because they judge that the risk of litigation for known earnings overstatements is high and urge management to correct them.

\subsection{A study of investors' reactions to news suggesting a correction}

Kinney and McDaniel (1989) showed that investors do not respond to date1, but subsequent studies on the subject have shown that the cumulative abnormal return (CAR) of date1 is a statistically significant negative. For example, GAO (2002) and GAO (2006) reported that the CARs for almost all years were statistically significant negative in their examination of 919 date1 news items (845 companies) from January 1997 to June 2002 and 1,390 date1 news items (1,121 companies) from July 2002 to September 2005, respectively. The authors report that the CAR for almost all years is statistically significantly negative and that the negative CAR has been shrinking since the early 2000 s due to a significant increase in economically insignificant corrections. Scholz (2008) and Scholz (2014) report similar results for 6,633 cases (4,786 firms) from January 1997 to December 2006 and 10,479 cases $(6,799$ firms) from January 2003 to December 2012, respectively. These results indicate that investors are unaware of misstatements and adjust their stock prices down when they learn of them on date1.

Some studies have focused on serious misstatements or fraud. For example, Griffin et al. (2004) examined the targets of class action lawsuits, while Beasley (2010) and Karpoff et al. (2008a) examined the targets of law enforcement by authorities. In India, Bhasin (2012) examines companies that disclosed the fact of inappropriate accounting treatment, Gupta (2015) examines the correction of net income, and Desai (2020) examines fraudulent financial reporting and misappropriation of assets (fraudulent accounting). These studies report that material misstatements and frauds have important negative impacts on investors, both statistically and economically.

\subsection{A study of investors' reactions to the misstatement of income (MST)}

Most of the subsequent studies related to this topic have examined the relationship between CAR and profit corrected value (MST) at dates and reported that the larger the MST, the larger the negative CAR (Gupta 2015, Lev et al. 2008, Palmrose et al. 2004, Wu 2002, and others). Because MST is unknown or undetermined at date1, some studies have examined the difference between the presence and absence of MST information at date1. For example, Gupta (2015), Lev et al. (2008), and Wu (2002) found that without MST information at date1, the negative CAR was statistically significantly larger than with MST information.

\subsection{Investor reaction to further information on the correction}

Although there are no studies that examine the reaction to MST-related information disclosed for the first time on date 2, there are many studies that examine the reaction of investors to related events 
that become apparent after date 1. For example, Beasley (2010) and Karpoff et al. (2008a) examine the progress of law enforcement by authorities after date 1, and Griffin et al. (2004) examine class-action lawsuits after date 1. In India, Desai (2020) examines the total reaction to each relevant disclosure between the first report of accounting fraud and the final investigation report or correction of the financial report that determines the content. These studies show that investors react to events that occur after dateı due to corrections, i.e., investors do not know all the economic consequences of corrections on datel.

\subsection{A study of investors' reactions to the completion of corrections}

However, Gupta (2015) examined the CAR of the date of the amendment to the financial statements, which is similar to date 3 , and found that investors had a smaller but statistically significant negative reaction to the amendment of the main table of financial statements and some notes than to date 1 . The results show that investors have a smaller but statistically significant negative reaction to a correction in the financial statement main table and some notes than to a correction in datel.

\subsection{Position of this paper in previous studies}

This paper builds on the results of the study that examined investors' reaction to the profit correction value (MST) in Section 2.2 and extends the study to the Indian stock market for the period up to 2019. These previous studies have examined the impact of MST on CAR with and without MST information at date1, but few have examined the difference in the impact of MST on CAR with and without MST information at datel. These studies also do not examine the reaction of investors to the MST information disclosed for the first time as a follow-up report, or to the correction report that resolves the uncertainty of the correction.

This paper is also related to studies that examined investors' reactions to news suggesting a correction in 2.1, studies that examined investors' reactions to follow-up news about a correction in 2.3, and studies that examined the CAR of the date of correction of financial statements that approximate the date of completion of the correction in 2.4. These studies examine investors' responses to relevant information after date1, but they do not examine the relationship between CAR and MST or the availability of MST-related information on datel. In addition, most of the previous studies have focused on the U.S. stock market, and there are few studies on the Indian stock market.

Therefore, in this paper, we examine the reaction of investors in date1, date2, and date 3 of the Indian stock market to comprehensively capture the impact of accounting fraud on investors' decision-making. By dividing the news into the existence of accounting manipulation, MST-related information, and the completion of correction, we clarify whether investors were misled by MST and whether there is a difference in investors' reaction depending on whether MST-related information is disclosed promptly or not. This paper also shows how the market penalizes managers who manipulate profits, and whether the severity of the penalty differs between cases where the information is disclosed promptly and cases where it is not.

\section{Hypothesis}

In the previous section, we confirmed the position of this paper in previous studies. In this section, we formulate a hypothesis based on the findings of the previous studies. We assume the following market efficiency and investor rationality.

It is generally believed that investors estimate corporate value according to corporate valuation models such as the dividend discount model, the DCF model, and the Allison model. In all of these models, the important inputs are future profits or cash flows (future flows) and the cost of capital (the risk of achieving them). Since these depend on the integrity and ability of management, investors use all available information to evaluate management and predict the future flows and the 
risk of achieving them. Stock prices fluctuate because investors quickly revise their expectations when they receive unknown information that affects them. Beaver et al. (1979) and Ball and Brown (1968) found that the sign of unexpected profits and the amount of unexpected profits affect the stock price.

If investors were unaware of the misstatement and used profits to make decisions on future cash flow projections, they would revise their projections downward in response to the amount of profit correction (MST). And if the MST is serious and attributable to fraud, stakeholders such as investors, customers, and employees will shun doing business with dishonest managers, resulting in lower sales and higher operating and financing costs. The cost of reviewing governance and internal controls, including management changes, and the risk of law enforcement and business failure also increases, and management's time is wasted in responding to these risks. Investors also take into account the decrease in future flows and the increase in risk caused by these factors. Consistent with this, several previous studies have shown that stock prices react negatively when corrections are announced and that the negative reaction to MST caused by significant MST or fraud is particularly large (Desai 2020, Gupta 2015, Lev et al. 2008, Palmrose et al. 2004, Wu 2002, etc.). From this, it can be inferred that investors were misled by the MST until the correction was announced.

On the other hand, some studies show that investors distrust accounting information, including MST, before the release of corrections (Dang et al. 2011). Studies on profit management show that investors may be able to estimate the existence and discretionary amount of profit management (Marquardt and Wiedman 2004, and Balsam et al. 2002, etc.). These studies indicate that investors may be able to estimate MST before the release of news suggesting accounting manipulation if management's motives are clear, or if they know about the existence of fraud even if it is skillfully concealed. However, the discovery of fraud has negative consequences for managers, such as damage to reputation, salary reduction, and loss of job (Beasley et al. 2010, Karpoff et al. 2008b, etc.). Therefore, managers have strong incentives to prevent information leakage by paying attention to prevent fraud from being seen from the outside. Therefore, even if investors can infer the existence of accounting manipulation and MST, the estimation error is considered to be large.

Based on the above discussion, the following hypotheses are formulated for the cumulative abnormal returns CARI, CARII, and CARIII on the date of the first news release suggesting accounting manipulation (dates), the date of the follow-up MST information that was not disclosed on datel (datez), and the date of the correction report indicating the resolution of uncertainty (date3). We set hypotheses for CARI, CARII, and CARIII by MST size and by the presence of MSTrelated information at dateı (dateı news content).

\subsection{Hypotheses related to CARI}

Previous studies on significant MST and fraud show that CARI is a statistically and economically significant negative (Gupta et al. 2015, Bhasin 2012, Beasley et al. 2010, Karpoff et al. 2008a,). These results are consistent with the argument at the beginning of this section that investors are unaware of MST and correct their prior expectations upon learning of the existence of accounting manipulation. From here, we formulate the following null hypothesis.

The null hypothesis 1-1: date1 news does not affect stock prices.

Considering that MST is the unexpected profit, the argument at the beginning of this section implies that the larger MST is, the larger the negative CARI is. Consistent with this, almost all previous studies have reported that the larger the MST, the larger the stock price decline (Desai 2020, Gupta 2015, Lev et al. 2008, Palmrose et al. 2004, Wu 2002, and others). From here, we formulate the following null hypothesis.

The null hypothesis 1-2: The impact on stock prices does not differ depending on the size of the MST.

From the discussion at the beginning of this section, if investors know the existence of accounting manipulation, they may be able to assess the severity of misstatement from other 
information even if MST is unknown. For example, if there is no information about MST in datel, we believe that the manipulation is complex and extensive, or that management is not competent and uncertainty is high. Consistent with this, many previous studies have shown that the negative effect of CARI is large when there is no MST information in date1 (Gupta 2015, Lev et al. 2008, Wu 2002, etc.). From this, we formulate the following null hypothesis.

The null hypothesis 1-3: date1 The effect of news content on stock prices does not differ.

\subsection{Hypothesis about CARII}

Unless the operation can be completely foreseen before date2, investors can use the follow-up reports of datez to increase the accuracy of their forecasts. As uncertainty is reduced, the risk of investing in stocks is reduced, and stock prices rise. On the other hand, if the follow-up report of datez shows that the operation is serious, the stock price will fall. Although there are no prior studies on investors' reaction to the first disclosure of MST information on date 2, many prior studies are showing that stock prices react to the progress of investigations and lawsuits filed by the authorities that become clear after date 1 (Griffin et al. 2004, Beasley et al. 2010, Karpoff et al. 2008a, etc.). From this, we formulate the following null hypothesis.

The null hypothesis 2-1: date2 news does not affect stock prices.

It is unlikely that investors will be able to fully foresee the MST-related information that could not be disclosed on date 1 even by managers with inside information before date 2 . Therefore, investors are expected to respond to the MST information disclosed on date 2. From here, we set the following null hypothesis. MST.

The null hypothesis 2-2: The impact on stock prices does not differ depending on the size of the

\subsection{Hypothesis about CARIII}

Although there is no prior research on date3, Gupta (2015) reports a negative CAR on the date of revision of financial statements. It is expected that a substantial part of the uncertainty in the amendments will be resolved by the amendment of the financial statements, but the uncertainty in complex and extensive amendments may remain until date 3, which indicates the completion of the audit. From this, we formulate the following null hypothesis.

The null hypothesis 3-1: date3 news does not affect stock prices.

The null hypothesis 3-2: There is no difference in the impact of MST size on stock prices.

The null hypothesis 3-3: date1 The effect of news content on stock prices does not differ.

\section{Sample Selection and its Basic Characteristics}

In this section, we describe how to select a sample for verification, and then confirm the basic characteristics of the sample by looking at descriptive statistics and cross-tabulation tables.

\subsection{Sample Selection}

This paper examines the period from the start of the fraud to the completion of the correction for firms whose accounting fraud was detected between January 1, 2007, and December 31, 2019. The firms that were found to have accounting irregularities are those that (i) were recommended to pay surcharges related to misstatements in their financial statements, (ii) were subject to actions by stock exchanges, and (iii) published press releases suggesting accounting manipulation. Although (i) through (iii) do not question the intent to "deceive users of financial statements," they were chosen as selection criteria because they were deemed by the authorities, stock exchanges, and the companies themselves to have a significant impact on investors' decision-making from the 
perspective of the system's purpose, they could not be corrected by an audit (audit failure), and their contents were revealed after the fact. The order of selection was as follows: first, firms that fell under (i), then firms that fell under (ii) but not (i), and finally firms that fell under (iii) but not (i) or (ii). For firms that fell into any of (i) to (iii) more than once, we selected the period that fell into the first category. Companies belonging to the financial industry and companies that went bankrupt or delisted before the submission of the correction report were excluded from the verification.

The subject of this paper is the misstatement of financial statements by the companies whose accounting frauds were discovered in the selected companies. We use returns net of control firm stock returns in this paper (Bardos et al. 2011). The control firms are firms other than the target firm whose fiscal year-end and industry are the same as those of the target firm and whose total assets at the end of the period immediately before the first news release (datel) that suggests accounting manipulation are the closest to those of the target firm. As a result of excluding control firms that meet this condition and other firms for which data necessary for the verification are not available from the scope of the verification, the number of firms to be verified and control firms is 232 firms/year, respectively.

The follow-up date (datez) for the information related to the accumulated net income correction (MST), which was not disclosed on datel and date1, was identified from the press release, and the date of filing of the correction report (date3) was identified from the correction report.

Date1 is the date of publication of a press release that includes expressions suggesting accounting manipulation, such as suspicions about inappropriate accounting treatment, possible correction of past fiscal years' financial statements, and establishment of an investigative committee. The net income before and after the correction was calculated manually from the annual securities report and the correction report. The stock prices were obtained from the 2019 NPM of Financial Data Solutions Inc.

\subsection{Descriptive statistics}

In this paper, we use the cumulative abnormal returns CARI, CARII, and CARIII for date1, date2, and date3, respectively, where CAR is the return after deducting the return on the stock of the control firm for the three days before and after the news release date $(-1,+1)$. We use these returns to control for size, industry, and spillover effects to similar firms (Gupta 2015, Gleason et al. 2008, Xu et al. 2006, etc.). The reason for using this cumulative period is to account for prior information leaks and the release of information after stock market trading hours; MST is the difference between pre-correction profit minus post-correction profit, deflated by total assets at the end of the year immediately preceding date1 to mitigate variance heterogeneity (Gupta 2015, Palmrose et al. 2004). These variables are winsorized at $2.5 \%$ each above and below to eliminate outliers.

CARI, CARII, and CARIII are divided into macro and micro MST (MACRO and MICRO), and the criterion for dividing MACRO and MICRO is the median MST. The MST is assumed to be zero in the case that no amendment report to the Annual Securities Report is submitted. CARI and CARIII are also separated by the presence or absence of MST-related information at date1 (date1 news content) (NO and NU).

The descriptive statistics for CARI, CARII, CARIII, and MST are summarized in table 1 by MACRO and MICRO and by NO and NU. Table 1 shows that the mean and median of CARI and CARII are negative for both MACRO and MICRO, NO, and NU, and the negative value of CARI for MACRO is the largest. From this, we can see that in most cases, stock prices fall on date1 and date2. It can also be seen that NO accounts for more than $40 \%$ of the total. The mean and median of CARIII are not as important as those of CARI and CARII for both MACRO and MICRO, NO, and NU, indicating that the stock price may increase significantly. The MST shows that most of the companies overstate their profits, and that the MST of NO is larger than that of NU, and that there are some companies with MST close to zero (including those that do not submit correction reports) and some companies that understate their profits. 
Table 1: CAR and MST for the full sample and by MST size and date1 news content

\begin{tabular}{|c|c|c|c|c|c|c|c|c|}
\hline variable & category & $\begin{array}{c}\text { sub } \\
\text { category }\end{array}$ & size & mean & std dev & $25^{\text {th }}$ percentile & $50^{\text {th }}$ percentile & $75^{\text {th }}$ percentile \\
\hline \multirow{5}{*}{ CARI } & & TOTAL & 232 & -0.0777 & 0.1072 & -0.1321 & -0.0524 & -0.0064 \\
\hline & TOTAL & MACRO & 116 & -0.0927 & 0.1073 & -0.1739 & -0.0675 & -0.0162 \\
\hline & TOTAL & MICRO & 116 & -0.0629 & 0.1054 & -0.0864 & -0.0334 & 0.0016 \\
\hline & TOTAL & NO & 96 & -0.0900 & 0.1181 & -0.1677 & -0.0598 & -0.0141 \\
\hline & & NU & 136 & -0.0691 & 0.0983 & -0.1233 & -0.0442 & -0.0031 \\
\hline \multirow{3}{*}{ CARII } & \multirow{3}{*}{$\begin{array}{l}\text { TOTAL } \\
\text { TOTAL }\end{array}$} & TOTAL & 96 & -0.0548 & 0.1256 & -0.1189 & -0.0364 & 0.0098 \\
\hline & & MACRO & 58 & -0.0577 & 0.1206 & -0.1207 & -0.0476 & 0.0013 \\
\hline & & MICRO & 38 & -0.0501 & 0.1348 & -0.1154 & -0.0242 & 0.0108 \\
\hline \multirow{5}{*}{ CARIII } & \multirow{5}{*}{$\begin{array}{l}\text { TOTAL } \\
\text { TOTAL } \\
\text { TOTAL }\end{array}$} & TOTAL & 185 & 0.0114 & 0.1334 & -0.0532 & -0.0001 & 0.0431 \\
\hline & & MACRO & 116 & 0.0282 & 0.1519 & -0.0525 & 0.0016 & 0.0643 \\
\hline & & MICRO & 69 & -0.0162 & 0.0904 & -0.0637 & -0.0023 & 0.0202 \\
\hline & & NO & 87 & 0.0287 & 0.1684 & -0.0545 & -0.0080 & 0.0919 \\
\hline & & $\mathrm{NU}$ & 98 & -0.0041 & 0.0901 & -0.0523 & 0.0031 & 0.0335 \\
\hline \multirow{5}{*}{ MST } & \multirow{5}{*}{$\begin{array}{l}\text { TOTAL } \\
\text { TOTAL } \\
\text { TOTAL }\end{array}$} & TOTAL & 232 & 0.0441 & 0.1096 & 0.0000 & 0.0034 & 0.0281 \\
\hline & & MACRO & 116 & 0.0889 & 0.1421 & 0.0131 & 0.0285 & 0.0885 \\
\hline & & MICRO & 116 & -0.0002 & 0.0030 & 0.0000 & 0.0000 & 0.0005 \\
\hline & & NO & 96 & 0.0671 & 0.1362 & 0.0000 & 0.0134 & 0.0461 \\
\hline & & NU & 136 & 0.0280 & 0.0830 & 0.0000 & 0.0019 & 0.0170 \\
\hline
\end{tabular}

CARI: dateiCAR (cumulative abnormal return) ;CARII: date2CAR (cumulative abnormal return); CARIII: date3CAR (Cumulative abnormal return); MST: 1 Accumulated consolidated net income correction per share, after deflating by total assets; MACRO: large amount of profit correction; MICRO: small amount of profit correction; NO: There is no information related to the amount of profit correction in dateı.; NU: There is information about the amount of profit correction in dateı.

4.3 Date1 Cross tabulation table of news content and frequency of occurrence of macro and micro profit corrections (MST)

Lev et al. (2008) reported that the amount of profit overstatement in NO is statistically significantly larger than that in NU. As shown in table 1, there is a possibility that there is a similar relationship among the subjects to be examined in this paper, in which case it will be necessary to control for the effects of each other. For this reason, we will check the relationship between the frequency of occurrence of $\mathrm{NO}$ and $\mathrm{NU}$ and that of MACRO and MICRO. The relationship between the two is summarized in table 2. Table 2 shows that the MST of NU (NO) is often MICRO (MACRO). The difference in the ratios is statistically significant as a result of the Chi-square test.

Table 2: Cross-tabulation of date1 news content and frequency of occurrence of MST macro and micro

\begin{tabular}{|c|c|c|c|}
\hline & MACRO & MICRO & Total \\
\hline \multirow{3}{*}{ NO } & 58 & 38 & 96 \\
NU & $50 \%$ & $33 \%$ & $41 \%$ \\
& 58 & 78 & 136 \\
\multirow{2}{*}{ Total } & $50 \%$ & $67 \%$ & $59 \%$ \\
& 116 & 116 & 232 \\
& $100 \%$ & $100 \%$ & $100 \%$ \\
\hline
\end{tabular}

Pearson $\chi^{2}(1)=8.8989 \mathrm{Pr}=0.003$; MACRO: large amount of profit correction; MICRO: small amount of profit correction; NO: There is no information related to the amount of profit correction in datel. ; NU: There is information about the amount of profit correction in datel.

\section{Validation Model and Results}

The hypothesis is tested by an event study. In this paper, we assume that investors receive information on the date of the first news release suggesting accounting manipulation (date1), the date of the follow-up report on the accumulated net income correction (MST) that was not disclosed on 
date1 (date2), and the date of the filing of the correction report (date3). The cumulative abnormal return (CAR) is the return after deducting the return on the stock of the control firm (Bardos et al. 2011) for three days before and after the news release date $(-1,+1)$.

The null hypotheses 1-1, 2-1, and 3-1 of Section 3 are tested by examining whether the CARI, CARII, and CARIII of date1, date2, and date3, respectively, are statistically significantly different from zero. A t-test is used for this validation. The null hypotheses 1-2, 2-2, 3-2, and 1-3, 3-3 are tested by looking at the MST size (MACRO and MICRO), whether it contains information related to the MST (date1 news content) (NO and NU), and whether there is a statistically significant difference in the CAR between each group. MST is the difference between pre-correction profit and post-correction profit, deflated by the total assets at the end of the year immediately preceding date 1 to mitigate variance heterogeneity (Gupta 2015, Palmrose et al. 2004). The criterion that separates MACRO from MICRO is the median MST. The MST is assumed to be zero when there is no correction in the securities report. We use a t-test and a U-test that take into account the heterogeneity of variances. In addition, since it was confirmed in the previous section that there is a statistically significant relationship between MST size and dateı news content, we will control for the influence of each other and conduct the verification. We will further divide the above groups into subgroups, namely, NO and NU, and MACRO and MICRO, in the same way as the group-specific tests.

As a result of the verification, if investors reacted to the existence of accounting manipulation, information about MST, and the filing of correction reports, we can assume that these news were surprises. From the sign and magnitude of the CAR, we can estimate how investors revised their expectations. If there is a difference in CAR between groups (or between subgroups), we know that the MST or dateı news content influences investors' decisions (controlling for each other's influence). Note that CARII is valid for NO and CARIII is valid for datez.

\subsection{Verification results for CARI}

The validation results are summarized in Table 3. First, looking at the full sample (TOTAL), CARI is statistically significant at about $-7 \%$, which is economically significant. This result rejects the null hypothesis 1-1 in Section 3 that the date1 news does not affect stock prices, indicating that investors are unaware of the accounting manipulation and thus adjust their expectations downward when they learn of its existence. The results show that investors are unaware of the accounting manipulation and thus adjust their expectations downward when they learn of its existence. The results for MACRO and MICRO of TOTAL show that CARI is about $-8 \%$ and $-5 \%$, respectively, and the difference is statistically significant. This result rejects the null hypotheses 1-2 in Section 3, which state that MST macro and micro do not affect stock prices, and indicates that investors adjust their expectations downward significantly when MST is large. However, looking at the breakdown of the results, the statistically significant difference is found in the case of NU, while the CARI of MACRO and MICRO is about $-10 \%$ and $-3 \%$, respectively. Finally, looking at NO and NU among TOTAL, CARI had a negative value of about $8 \%$ and about $6 \%$, respectively, but the difference was not statistically significant. This result does not allow us to reject the null hypotheses 1-3 in Section 3, which state that the effect of date1 news content on stock prices does not differ. However, a breakdown of the results shows that the CARI of NO and NU among MICRO is $-10 \%$ and $-3 \%$, respectively, a statistically significant difference.

These results indicate that there is an association between MST and stock price declines, but without MST-related information, investors are unable to decompose the amount of management manipulation and react uniformly, resulting in an overreaction when MST is micro.

\subsection{Verification results for CARII}

The verification results are summarized in Table 3. First, looking at TOTAL, CARII has a statistically significant negative value of about $4 \%$, which is economically important. This result rejects the null 
hypothesis 2-1 in Section 3 that datez news does not affect stock prices. In the case of MACRO and MICRO of TOTAL, the statistically significant difference in CARII was about $5 \%$, which was not statistically significant. This result does not allow us to reject the null hypothesis 2-2 in Section 3, which states that the impact of MST size on stock prices is not different. However, the stock price decline in NO is larger than that in NU when the results of CARI are taken into account.

\subsection{Verification results for CARIII}

The validation results are summarized in table 3. First, looking at TOTAL, CARIII was not statistically significantly different from zero. This result does not allow us to reject the null hypothesis 3-1 in Section 3 that date 3 news does not affect stock prices. Looking at MACRO and MICRO among TOTAL, the difference in CARIII is statistically significant in the t-test but weakly statistically insignificant in the U-test. There was no statistically significant difference in the CARIII of NO and NU among TOTAL. These results do not allow us to reject the null hypotheses 3-2 in Section 3, which states that the impact on stock prices does not differ depending on the MST size, and 3-3 in Section 3, which states that the impact on stock prices does not differ depending on the dater news content. However, the difference in CARIII between MACRO and MICRO among NO is positive and statistically significant by both t-test and U-test. The CARIII of NO and MACRO is statistically significant plus $5 \%$, which is also economically important. The difference in CARIII between NO and NU among MICRO is negative and statistically significant in the U-test. These results indicate that in the case of MACRO and NO, investors' concerns remain until date 3 and the market favors the removal of uncertainty due to the completion of the correction.

Table 3: Verification results for CARI, CARII, and CARIII

\begin{tabular}{|c|c|c|c|c|c|c|c|}
\hline Variable & Category & $\begin{array}{c}\text { sub } \\
\text { Category }\end{array}$ & Obs & Mean & S.E. & t-value & z-value \\
\hline \multirow[t]{19}{*}{ CARI } & TOTAL & TOTAL & 232 & $-0.0 B$ & 0.01 & $-11.07 \cdots$ & \\
\hline & TOTAL & MACRO & 116 & -0.09 & 0.01 & $-9.31 * * *$ & \\
\hline & & MICRO & 116 & -0.06 & 0.01 & $-6.45 * \bullet$ & \\
\hline & & \multicolumn{2}{|c|}{ difference } & -0.03 & 0.01 & $-2.14 * *$ & $-2.80 * 4$ \\
\hline & \multirow[t]{3}{*}{ No } & MACRO & 58 & -0.08 & 0.01 & $-5.81 * * *$ & \\
\hline & & MICRO & 38 & -0.11 & 0.02 & $-4.77 * * *$ & \\
\hline & & \multicolumn{2}{|l|}{ difference } & 0.03 & 0.03 & 1.07 & 0.38 \\
\hline & \multirow[t]{3}{*}{ NU } & MACRO & 58 & -0.11 & 0.01 & $-7.38 * * *$ & \\
\hline & & MICRO & 78 & -0.04 & 0.01 & $-4.71 * *$ & \\
\hline & & \multicolumn{2}{|c|}{ difference } & -0.06 & 0.02 & $-3.79^{* * *}$ & $-3.57^{* * *}$ \\
\hline & \multirow[t]{3}{*}{ TOTAL } & NO & 96 & -0.09 & 0.01 & $-7.47 * \bullet \bullet$ & \\
\hline & & NU & 136 & -0.07 & 0.01 & $-8.23 * * *$ & \\
\hline & & \multicolumn{2}{|c|}{ difference } & -0.02 & 0.01 & -1.42 & -1.58 \\
\hline & \multirow[t]{2}{*}{ MACRO } & NO & 58 & -0.08 & 0.01 & $-5.81 * * *$ & \\
\hline & & NU & 58 & -0.11 & 0.01 & $-7.38 * * *$ & \\
\hline & & \multicolumn{2}{|c|}{ difference } & 0.03 & 0.02 & 1.39 & 1.11 \\
\hline & \multirow[t]{2}{*}{ MICRO } & No & 38 & -0.11 & 0.02 & $-4.77 * * \bullet$ & \\
\hline & & NU & 78 & -0.04 & 0.01 & $-4.71 * *$ & \\
\hline & & \multicolumn{2}{|c|}{ difference } & -0.06 & 0.02 & $-2.68 * * \bullet$ & $-2.44 * *$ \\
\hline \multirow[t]{4}{*}{ CARII } & TOTAL & TOTAL & 96 & -0.05 & 0.01 & $-4.27^{* * *}$ & \\
\hline & \multirow[t]{2}{*}{ TOTAL } & MACRO & 58 & -0.06 & 0.02 & $-3.68 * * *$ & \\
\hline & & MICRO & 38 & -0.05 & 0.02 & $-2.26^{* *}$ & \\
\hline & & \multicolumn{2}{|c|}{ difference } & -0.01 & 0.03 & -0.28 & -0.62 \\
\hline
\end{tabular}




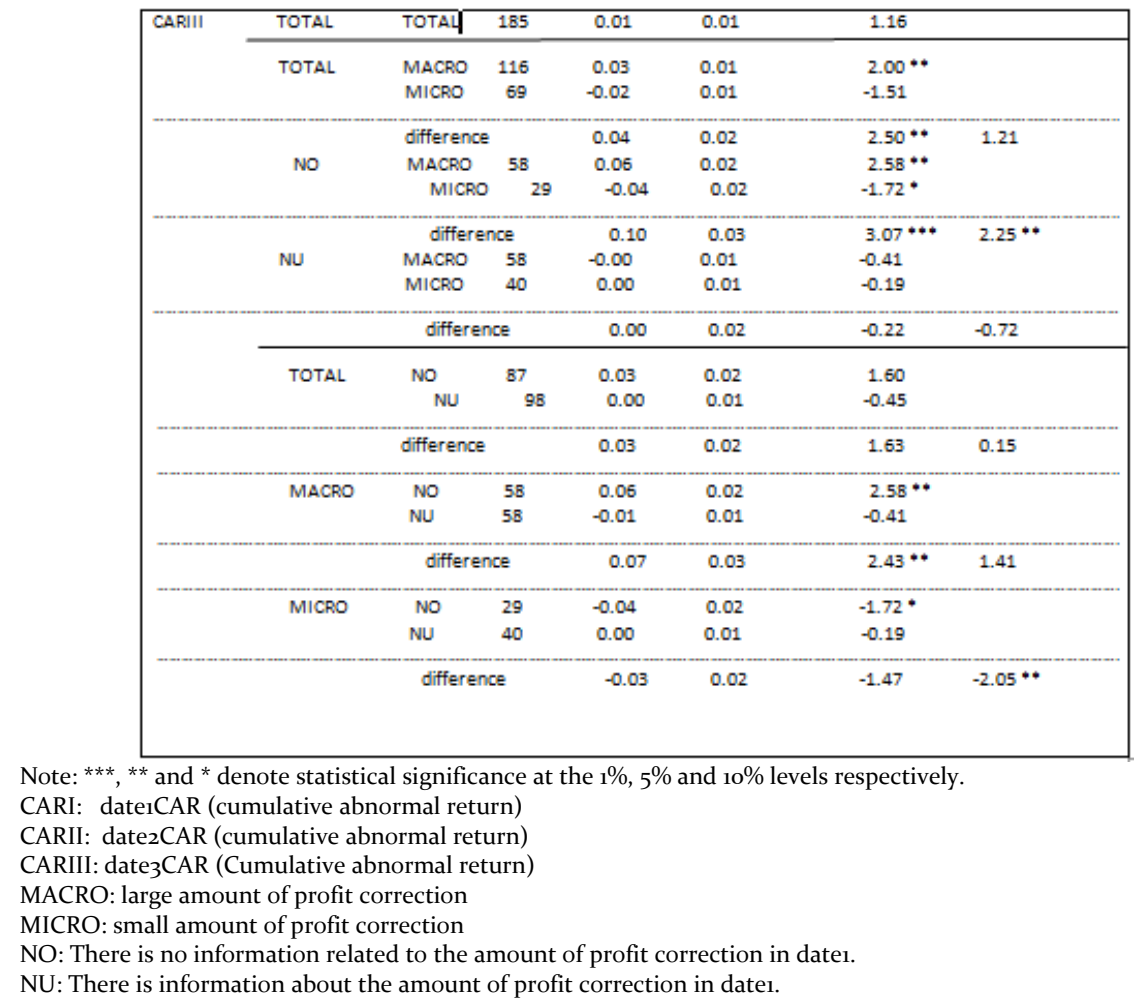

\subsection{Summary}

The results of the verification show that stock prices fall sharply on date1 and date2, that when MST is macro and it takes time to disclose MST-related information, stock prices rebound on date 3 in response to the resolution of uncertainty, and that there is a relationship between MST and the size of the stock price decline. However, when there is no information about MST at datel, investors react uniformly, and the reaction to a macro (micro) MST is underreaction (overreaction). These results indicate that investors were misled by MST until the fraud was discovered and made decisions based on overestimates of future cash flows, so they suffered unexpected losses when the fraud was discovered, and during the period from the fraud discovery to the completion of the correction. Although the expectations were revised appropriately using the MST-related information (including its existence or non-existence), the information was noisy, indicating that the stock price fluctuated wildly during that period. These results also show that investors penalize managers who are not serious but fail to disclose this fact promptly.

\section{Additional Validation and Robustness Verification}

The results of the previous section show that stock prices fall sharply on the date of the first news release suggesting accounting manipulation (dateı) and on the date of the follow-up news release of information related to accumulated net income adjustments (MST) that was not disclosed on date1 (date2), and that there is a relationship between the size of MST and the magnitude of stock price decline. However, when there is no information about MST, investors react uniformly, and thus the reaction to a macro (micro) MST is underreaction (overreaction). The results of the previous section also reveal that when MST is macro and it takes time to disclose information related to MST, stock 
prices rebound on the date of filing of the amendment report (date3) in response to the resolution of uncertainty. Since these results are based on the dichotomization of MST into macro and micro (MACRO and MICRO), to confirm that important information is not lost by this dichotomization, we conduct additional verification in this section by replacing MST macro and micro with MST. However, since there is room for subjective judgments to intervene in the selection of control firms, in this section, we change the measurement method of CAR to verify the robustness of the results in the previous section.

\subsection{Additional validation}

The following model (1) and model (2) are used for the validation in this section.

$\mathrm{CAR}=\mathrm{a}_{0}+\mathrm{b}_{1} \mathrm{MST}+\varepsilon$

$\mathrm{CAR}=\mathrm{a}_{0}+\mathrm{a}_{1} \mathrm{~d} \_\mathrm{NO}+\mathrm{b}_{1} \mathrm{MST}+\mathrm{b}_{2} \mathrm{MST} * \mathrm{~d} \_\mathrm{NO}+\varepsilon$

MST is the difference between pre-correction profit and post-correction profit, deflated by total assets at the end of the year immediately preceding date1 to mitigate variance heterogeneity (Gupta 2015, Palmrose et al. 2004). d_NO is a dummy variable that is set to one if there is no information on MST at date1 and zero otherwise. Variables other than the dummy variables are winsorized at $2.5 \%$ each to eliminate outliers. The other variables are the same as in the previous section. To deal with the heterogeneity of variance, robust estimation is used.

Model ( 1 ) is tested by looking at the statistical significance and sign of $b_{1}$ because a larger MST indicates a larger decline in stock prices if $b_{1}$ is a statistically significant negative. Model (2) is tested by examining the statistical significance and sign of $b_{1}, b_{2}$, and $b_{1}+b_{2}$ when $b_{2}$ is statistically significantly different from zero, or when one of $b_{1}$ and $b_{1}+b_{2}$ is statistically significantly different from zero and the other is not. On the other hand, if this is not the case, the impact of MST on stock prices depends on the content of datel news. The target of CARII is the one with d_NO set to 1, and the target of CARIII is the one with date3.

The results of the validation are summarized in table 4. First of all, the results of model (1) show that $b_{1}$ for CARI and CARII is statistically (at the $10 \%$ level) significant negative. $b_{1}$ for CARIII is statistically (at the $10 \%$ level) significant positive. These results indicate that the larger the MST, the larger the stock price decline in date1 and date2, and the larger the stock price rebound in datez. The results of model (2) show that $b_{1}\left(b_{2}\right)$ of CARI is statistically significant negative (positive), and $b_{1}+b_{2}$ is not statistically significantly different from zero. The coefficient of d_NO was statistically significant negative. These results indicate that investors adjust their expectations downward in response to MST if MST information is disclosed, but fail to respond to MST if MST information is not disclosed, and penalize themselves for failing to disclose MST information. $b_{1}$ and $b_{2}$ in CARIII are not statistically significant, but $b_{1}+b_{2}$ are statistically significant positive. This result indicates that investors prefer to complete corrections when MST is large and there is no MST-related information in datel.

In summary, the results in this section are similar to those in Section 5, except that MST was shown to affect stock prices in datez as well.

Table 4: Regression Results

$\mathrm{CAR}=\mathrm{a}_{\mathrm{o}}+\mathrm{b}_{1} \mathrm{MST}+\varepsilon \quad(1)$

$$
\mathrm{CAR}=\mathrm{a}_{\mathrm{o}}+\mathrm{a}_{1} \mathrm{~d} \_\mathrm{NO}+\mathrm{b}_{1} \mathrm{MST}+\mathrm{b}_{2} \mathrm{MST} * \mathrm{~d} \_\mathrm{NO}+\varepsilon
$$




\begin{tabular}{|c|c|c|c|c|}
\hline \multicolumn{2}{|c|}{$\begin{array}{l}\text { Model (1) } \\
\text { Variable }\end{array}$} & $\begin{array}{c}\text { CARI } \\
\text { Coefficient / [ } t \text { value] }\end{array}$ & $\begin{array}{c}\text { CARII } \\
\text { Coefficient / } t \text { value] }\end{array}$ & $\begin{array}{c}\text { CARIII } \\
\text { Coefficient / [t value] }\end{array}$ \\
\hline$\dot{b}_{1}$ & $\begin{array}{l}\text { MST } \\
\text { Constant }\end{array}$ & $\begin{array}{l}-0.147 \\
{[-1.81]^{*}} \\
-0.0712 \\
{[-9.81]^{* * *}}\end{array}$ & $\begin{array}{l}-0.1686 \\
{[-1.82]^{*}} \\
-0.0435 \\
{[-3.13]^{* * *}}\end{array}$ & $\begin{array}{l}0.3599 \\
{[2.92]^{* * *}} \\
-0.0084 \\
{[-0.91]}\end{array}$ \\
\hline $\begin{array}{l}\text { Adj } \\
\mathrm{Siz}\end{array}$ & $\mathrm{dR}^{2}$ & $\begin{array}{r}0.0184 \\
232\end{array}$ & $\begin{array}{r}0.0231 \\
96\end{array}$ & $\begin{array}{r}0.0997 \\
185\end{array}$ \\
\hline
\end{tabular}

Note: $* * *, * *$ and $*$ denote statistical significance at the $1 \%, 5 \%$ and $10 \%$ levels respectively.

\begin{tabular}{|c|c|c|c|}
\hline \multicolumn{2}{|c|}{$\begin{array}{l}\text { Model (2) } \\
\text { Variable }\end{array}$} & \multirow{5}{*}{$\begin{array}{c}\text { CARI } \\
\text { Coefficient / [t value] } \\
-0.4587 \\
{[-5.74]^{* * *}} \\
0.4963 \\
{[3.92]^{* * *}} \\
-0.0363 \\
{[-2.35]^{* *}} \\
-0.0562 \\
{[-7.01]^{* *}}\end{array}$} & \multirow{5}{*}{$\begin{array}{c}\begin{array}{c}\text { CARIII } \\
\text { Coefficient / [t value] }\end{array} \\
0.2478 \\
{[0.95]} \\
0.1512 \\
{[0.52]} \\
0.0132 \\
{[0.66]} \\
-0.0137 \\
{[-1.42]}\end{array}$} \\
\hline$b_{1}$ & MST & & \\
\hline$b_{2}$ & MST_NO & & \\
\hline & d_NO & & \\
\hline & Constant & & \\
\hline \multicolumn{2}{|c|}{ Linear constraints } & Coefficient / [ $F$ value] & Coefficient / [F-value] \\
\hline$b_{1}+b_{2}$ & $\mathrm{MST}+\mathrm{MST} * \mathrm{~d}_{-} \mathrm{NO}$ & $\begin{array}{l}0.0376 \\
{[0.15]}\end{array}$ & $\begin{array}{l}0.399 \\
{[9.16]^{* * *}}\end{array}$ \\
\hline Adjust & & 0.0723 & 0.1001 \\
\hline
\end{tabular}

Note: $* * *,{ }^{* *}$ and ${ }^{*}$ denote statistical significance at the $1 \%, 5 \%$ and $10 \%$ levels respectively.

CARI: dateiCAR (abnormal return)

CARII: date2CAR (abnormal return)

CARIII: date3CAR (abnormal return)

MST: 1 Accumulated consolidated net income correction per share, after deflating by total assets

d_NO: A dummy variable that is set to one if there is no information on the amount of profit correction in dater and zero otherwise.

\subsection{Robustness verification}

In this section, we first use returns of the Bombay Stock Exchange as CARs. The target of this validation is 238 firms, including those excluded from the validation in the previous section because the control firms could not be identified. The results of the validation are summarized in tables 5 and 6. Next, like CAR, we use the stock returns of the control firms that were selected by adding the listed market to the selection criteria in the previous section. The number of firms to be tested is 204, excluding those for which the control firm cannot be identified. The results of the verification are summarized in tables 7 and 8. There is no difference in any of the results affecting the main results in Section 5, and the results in Section 5 are confirmed to be robust regardless of the measurement method of CAR.

Table 5: Validation results for CARI, CARII, and CARIII (after deducting BSE returns)

\begin{tabular}{|c|c|c|c|c|c|c|c|}
\hline Variable & Category & $\begin{array}{c}\text { Sub } \\
\text { Category }\end{array}$ & Obs & Mean & S. E. & $\mathbf{t}$ & $\mathbf{z}$ \\
\hline \multirow[t]{4}{*}{ CARI } & TOTAL & TOTAL & 238 & -0.0686 & 0.0060 & $-11.35^{* * *}$ & \\
\hline & TOTAL & MACRO & 118 & -0.0924 & 0.0085 & $-10.82 * * *$ & \\
\hline & & MICRO & 120 & $-0.045^{\circ}$ & 0.0080 & $-5.61 * * *$ & \\
\hline & & differen & & -0.0474 & 0.0117 & $-4.04 * * *$ & $-4.70 * * *$ \\
\hline
\end{tabular}




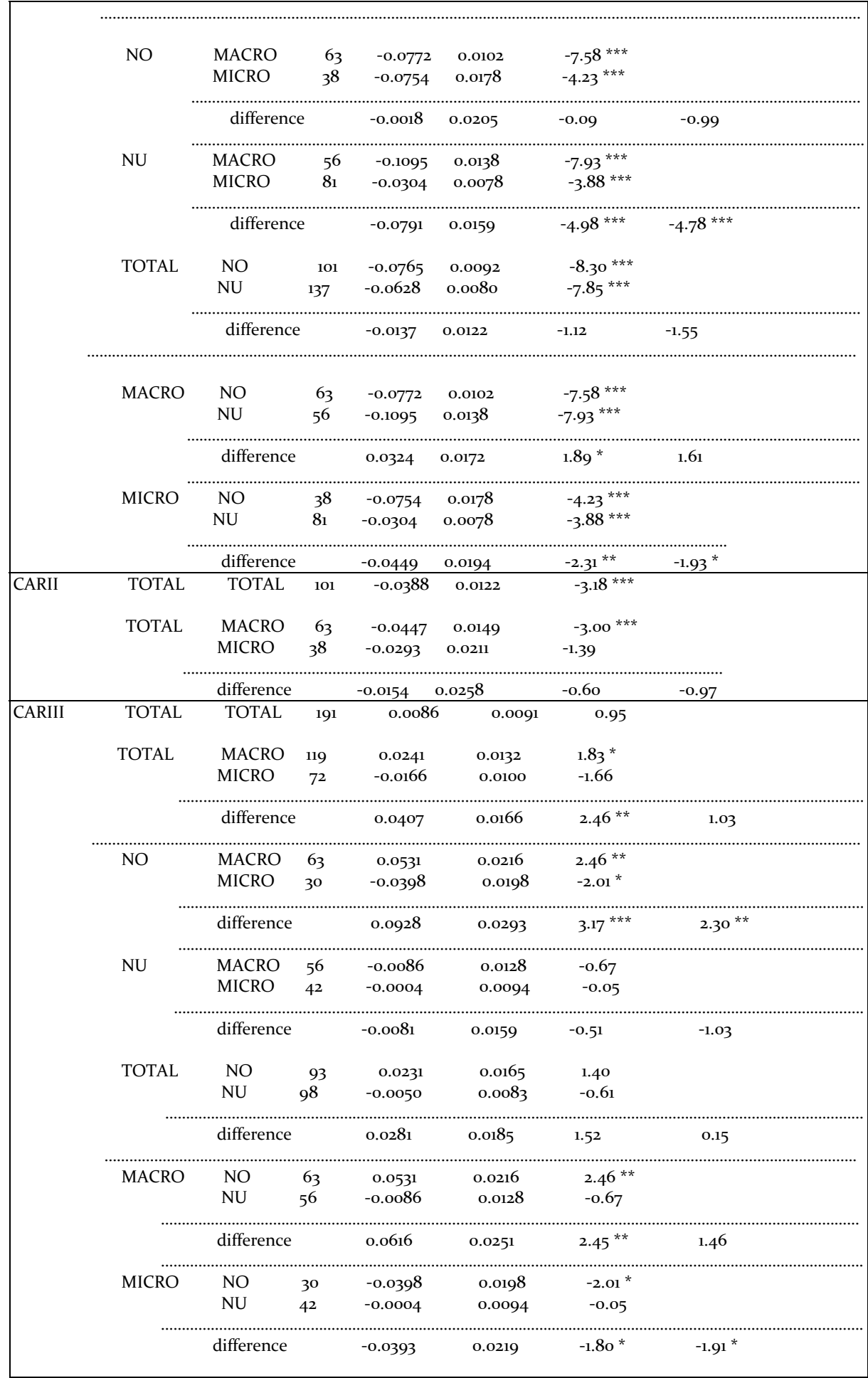


Note: *** ** and * denote statistical significance at the $1 \%, 5 \%$ and $10 \%$ levels respectively.

CARI: dateiCAR (cumulative abnormal return); CARII: date2CAR (cumulative abnormal return); CARIII: date3CAR (Cumulative abnormal return); MACRO: large amount of profit correction; MICRO: small amount of profit correction; NO: There is no information related to the amount of profit correction in date1.; NU: There is information about the amount of profit correction in date1.

Table 6: Regression results (after deduction of BSE returns)

$\mathrm{CAR}=\mathrm{a}_{\mathrm{o}}+\mathrm{b}_{1} \mathrm{MST}+\varepsilon$

$C A R=a_{0}+a_{1} d \_N O+b_{1} M S T+b_{2} M S T * d \_N O+\varepsilon$

\begin{tabular}{lcccc}
$\begin{array}{l}\text { Model(1) } \\
\text { Variable }\end{array}$ & $\begin{array}{c}\text { CARI } \\
\text { Coefficient / [t value] }\end{array}$ & $\begin{array}{c}\text { CARII } \\
\text { Coefficient / [t value] }\end{array}$ & $\begin{array}{c}\text { CARIII } \\
\text { Coefficient / [ t value] }\end{array}$ \\
\hline Tor & MST & -0.208 & -0.2102 & 0.3088 \\
& & {$[-3.25]^{* * *}$} & {$\left[-2.311^{* *}\right.$} & {$[2.50]^{* *}$} \\
& Constant & -0.0596 & -0.0252 & -0.0082 \\
& {$[-9.55]^{* * *}$} & {$[-1.95]^{*}$} & {$[-0.94]$} \\
\hline \multirow{2}{*}{$\begin{array}{l}\text { Adjusted } R^{2} \\
\text { Size }\end{array}$} & 0.0542 & 0.0419 & 0.0793 \\
& 238 & 101 & 191 \\
\hline
\end{tabular}

Note: ${ }^{* * *},{ }^{* *}$ and ${ }^{*}$ denote statistical significance at the $1 \%, 5 \%$ and $10 \%$ levels respectively.

\begin{tabular}{|c|c|c|c|}
\hline \multicolumn{2}{|c|}{$\begin{array}{l}\text { Model (2) } \\
\text { Variable }\end{array}$} & \multirow{6}{*}{$\begin{array}{c}\text { CARI } \\
\text { Coefficient / [t value] } \\
-0.4852 \\
{[-7.01]^{* * *}} \\
0.4304 \\
{[4.11]^{* * *}} \\
-0.0238 \\
{[-1.86]^{*}} \\
-0.0492 \\
{[-6.57]^{* * *}}\end{array}$} & \multirow{6}{*}{$\begin{array}{c}\text { CARIII } \\
\text { Coefficient / [ } t \text { value] } \\
0.2003 \\
{[0.78]} \\
0.1483 \\
{[0.51]} \\
0.0112 \\
{[0.61]} \\
-0.0128 \\
{[-1.43]}\end{array}$} \\
\hline $\mathrm{b}_{1}$ & MST & & \\
\hline$b_{2}$ & & & \\
\hline & d_NO & & \\
\hline & & & \\
\hline & Constant & & \\
\hline \multicolumn{2}{|c|}{ Linear constraints } & Coefficient / [F value] & Coefficient / [ $F$ value] \\
\hline$b_{1}+b$ & MST+MST*d_NO & $\begin{array}{l}-0.0548 \\
{[0.48]}\end{array}$ & $\begin{array}{l}0.3486 \\
{[6.52]^{* *}}\end{array}$ \\
\hline $\begin{array}{l}\text { Adju } \\
\text { Size }\end{array}$ & & $\begin{array}{r}0.1027 \\
238\end{array}$ & $\begin{array}{r}0.0793 \\
191\end{array}$ \\
\hline
\end{tabular}

Note: ${ }^{* * *}, * *$ and $*$ denote statistical significance at the $1 \%, 5 \%$ and $10 \%$ levels respectively.

CARI: date1CAR (abnormal return); CARII: date2CAR (abnormal return); CARIII: date3CAR (abnormal return); MST: 1 Accumulated consolidated net income correction per share, after deflating by total assets; d_NO: A dummy variable that is set to one if there is no information on the amount of profit correction in dates and zero otherwise.

Table 7: Validation results for CARI, CARII, and CARIII (after deducting another control firm stock return)

\begin{tabular}{|c|c|c|c|c|c|c|c|}
\hline Variable & Category & $\begin{array}{c}\text { Sub } \\
\text { ategory }\end{array}$ & Obs & Mean & S.E. & $\mathbf{t}$ & $\mathbf{z}$ \\
\hline \multirow[t]{4}{*}{ CARI } & ALL & TOTAL & 204 & -0.07 & 0.01 & $-10.14^{* * *}$ & \\
\hline & \multirow[t]{3}{*}{ TOTAL } & MACRO & 102 & -0.09 & 0.01 & $-9.45^{* * *}$ & \\
\hline & & differen & & -0.04 & 000 & $-216 * * *$ & $-28, * * *$ \\
\hline & & . & & -0.04 & 0.01 & -3.10 & -3.01 \\
\hline
\end{tabular}




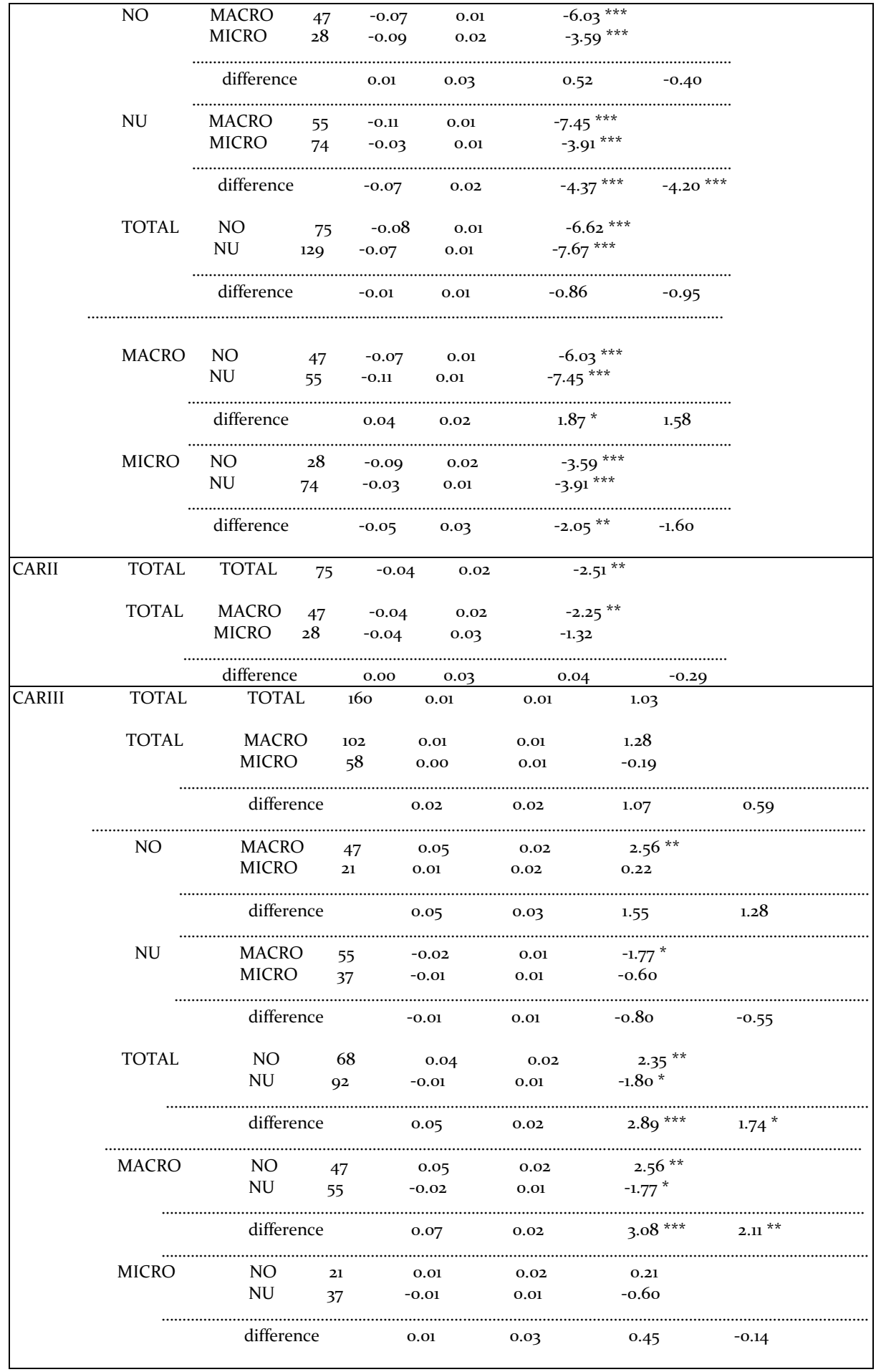


Note: ***, ** and * denote statistical significance at the $1 \%, 5 \%$ and $10 \%$ levels respectively.

CARI: dateiCAR (cumulative abnormal return)

CARII: date2CAR (cumulative abnormal return)

CARIII: date3CAR (Cumulative abnormal return)

MACRO: large amount of profit correction

MICRO: small amount of profit correction

NO: $\quad$ There is no information related to the amount of profit correction in date1.

NU: There is information about the amount of profit correction in datel.

Table 8: Regression results (net of another control firm stock return)

$\mathrm{CAR}=\mathrm{a}_{0}+\mathrm{b}_{1} \mathrm{MST}+\varepsilon$

$\mathrm{CAR}=\mathrm{a}_{0}+\mathrm{a}_{1} \mathrm{~d} \_\mathrm{NO}+\mathrm{b}_{1} \mathrm{MST}+\mathrm{b}_{2} \mathrm{MST} * \mathrm{~d} \_\mathrm{NO}+\varepsilon$

\begin{tabular}{|c|c|c|c|c|}
\hline & & $\begin{array}{l}\text { CARI } \\
\text { Coefficient / [ } t \text { value] }\end{array}$ & $\begin{array}{l}\text { CARII } \\
\text { Coefficient / [ } t \text { value] }\end{array}$ & $\begin{array}{l}\text { CARIII } \\
\text { Coefficient / [ } t \text { value] }\end{array}$ \\
\hline$\overline{p_{1}}$ & & $\begin{array}{l}-0.2109 \\
{[-2.56]^{* *}}\end{array}$ & $\begin{array}{l}-0.1911 \\
{[-1.59]}\end{array}$ & $\begin{array}{l}0.2434 \\
{[1.96]^{*}}\end{array}$ \\
\hline & Constant & $\begin{array}{l}-0.0624 \\
{[-8.66]^{* * *}}\end{array}$ & $\begin{array}{l}-0.026 \\
{[-1.52]}\end{array}$ & $\begin{array}{r}-0.0039 \\
{[-0.47]}\end{array}$ \\
\hline & & 0.0387 & 0.0225 & 0.0571 \\
\hline Size & & 204 & 75 & 160 \\
\hline
\end{tabular}

Note: ${ }^{* * *},{ }^{* *}$ and ${ }^{*}$ denote statistical significance at the $1 \%, 5 \%$ and $10 \%$ levels respectively.

\begin{tabular}{cccc}
$\begin{array}{l}\text { Model (2) } \\
\text { Variable }\end{array}$ & $\begin{array}{c}\text { CARI } \\
\text { Coefficient / [t value] }\end{array}$ & $\begin{array}{c}\text { CARIII } \\
\text { Coefficient } /[\text { t value }\end{array}$ \\
\hline $\mathrm{b}_{1}$ & MST & -0.5078 & -0.027 \\
$\mathrm{~b}_{2}$ & MST_NO & {$[-4.47]^{* * *}$} & {$[-0.18]$} \\
& & 0.4304 & 0.3328 \\
& d_NO & {$[2.70]^{* * *}$} & {$[1.61]$} \\
& \multirow{2}{*}{ Constant } & -0.0196 & 0.0277 \\
& & {$[-1.25]$} & {$[1.54]$} \\
& & -0.0539 & -0.0125 \\
& & {$[-6.63]^{* * *}$} & {$[-1.59]$}
\end{tabular}

\begin{tabular}{lcc}
\hline Linear constraints & Coefficient $/[\mathrm{F}$ value $]$ & Coefficient $/[\mathrm{F}$ value $]$ \\
\hline $\mathrm{b}_{1}+\mathrm{b}_{2} \quad \mathrm{MST}+\mathrm{MST}$ d_NO $_{-}$ & -0.0774 & 0.3058 \\
& {$[0.48]$} & $[4.68]]^{* *}$ \\
\hline Adjusted $\mathrm{R}^{2}$ & 0.0664 & 0.1092 \\
Size & 204 & 160
\end{tabular}

Note: ${ }^{* * *},{ }^{* *}$ and ${ }^{*}$ denote statistical significance at the $1 \%, 5 \%$ and $10 \%$ levels respectively.

CARI: dateiCAR (abnormal return)

CARII: date2CAR (abnormal return)

CARIII: date3CAR (abnormal return)

MST: 1 Accumulated consolidated net income correction per share, after deflating by total assets

d_NO: A dummy variable that is set to one if there is no information on the amount of profit correction in date1 and zero otherwise.

\section{Conclusion}

In this paper, we examined the period from the discovery of accounting fraud to the completion of the correction and examined how investors reacted to the first news release suggesting accounting manipulation, whether they reacted with anticipation of the unknown or undetermined amount of the correction, whether they reacted with anticipation of the severity of the correction based on the availability of information about the amount of the correction, and whether the effect of the correction on investors depended on the availability of information about the amount of the 
correction on the first news release. In addition, we also examined the date of the filing of the correction report, which indicates the resolution of the uncertainty of the correction and the date of the follow-up report for the information related to the amount of profit correction that was not disclosed on the date of the first news release.

As a result of the verification, it can be said that the stock price falls sharply on the day of the first news release and the day when the information about the amount of the profit revision is disclosed, that when the amount of the profit revision is large and it takes time to disclose the information about the amount of the profit revision, there is a rebound in the stock price on the day when the correction report is submitted because investors like the resolution of uncertainty, and that there is a relationship between the amount of the profit revision and the size of the stock price decline. However, when there is no information about the amount of correction on the first day of the news release, investors react uniformly, and the reaction to a large (small) amount of correction is underreaction (overreaction). These results indicate that investors were misled by the misstatements until the fraud was discovered and made decisions based on overestimates of future cash flows, so they suffered unexpected losses when the fraud was discovered, and during the period from the fraud discovery to the completion of the correction. Although the expectations were revised appropriately using the disclosed information on the amount of profit correction (including the presence or absence of it), the information was noisy, indicating that the stock price fluctuated wildly during that period. These results also show that investors penalize managers who are not serious but fail to disclose this fact promptly.

In this paper, we used an event study to examine the information value or content of each news item by identifying the date of the first news release, the date of the follow-up information on the amount of profit correction, and the date of the filing of the correction report, and the stock price reaction (return) at each of these dates. In the event study, it is necessary to identify the point in time when investors obtain the information, the unexpected information (surprise), and the estimation of abnormal returns, but there is room for subjective judgment to intervene in these decisions. This paper does not examine information other than the amount of profit corrections available to investors on the three event dates identified in this paper and whether or not the initial news contains information about profit corrections. Since this paper focuses on yearly corrections, the effect of quarterly corrections is also subject to verification. To enhance the usefulness of the results obtained in this paper, it is necessary to accumulate empirical results on other factors affecting stock prices that could not be verified in this paper, using assumptions and methods other than those adopted in this paper.

Despite the limitations mentioned above, it can be said that this paper has contributed to the accumulation of empirical results that comprehensively capture the impact of accounting fraud on investors' decision making by dividing the news related to accounting fraud into the existence of accounting manipulation, information related to the amount of profit correction, and the completion of correction. It is a contribution of this paper to the literature.

\section{Acknowledgement}

The author Dr. Syed Raziuddin Ahmad would like to thanks Arab Open University, Saudi Arabia for supporting him for this research paper.

\section{References}

Ball, R., \& Brown, P. (1968). An empirical evaluation of accounting income numbers. Journal of Accounting Research, 6(2), 159-178. https://doi.org/10.2307/2490232

Balsam, S., Bartov, E., \& Marquardt, C. (2002). Accruals management, investor sophistication, and equity valuation: Evidence from 10-Q filings. Journal of Accounting Research, 40(4), 987-1012. https://doi.org/10.1111/1475-679X.0oo79 
Bardos, K. S., Golec, J., \& Harding, J. P. (2011). Do investors see through mistakes in reported earnings? Journal of Financial and Quantitative Analysis, 46(6), 1917-1946. https://doi.org/10.1017/Soo22109011000470

Beasley, M. S., Carcello, J. V., Hermanson, D. R., \& Neal, T. L. (1999). 'Fraudulent Financial Reporting: 1987-1997, An Analysis of U. S. Public Companies,' The Committee of Sponsoring Organizations of the Treadway commission.

Beasley, M. S., Carcello, J. V., Hermanson, D. R., \& Neal, T. L. (2010). 'Fraudulent Financial Reporting: 1998-2007, An Analysis of U. S. Public Companies,' The Committee of Sponsoring Organizations of the Treadway commission.

Beaver, W. H., Clarke, R., \& Wright, W. F. (1979). The association between unsystematic security returns and the magnitude of earnings forecast errors. Journal of Accounting Research, 17(2), 316-340. https://doi.org/10.2307/2490507

Bhasin, M. L. (2012). Corporate accounting frauds: A case study of Satyam Computers Limited. International Journal of Contemporary Business Studies. Oct., 3(10), 16-42

Dang, L., Brown, K. F., \& McCullough, B. D. (2011). Apparent audit failures and value relevance of earnings and book value. Review of Accounting and Finance, 10(2), 134-154. https://doi.org/10.1108/14757701111129616

Desai, N. (2020). Understanding the theoretical underpinnings of corporate fraud. Vikalpa: The Journal for Decision Makers, 45(1), 25-31. https://doi.org/10.1177/0256090920917789

GAO. (2002). Financial statement restatements: Trends, market impacts, regulatory responses, and remaining challenges.

GAO. (2006). Financial restatements: Update of public company trends, market impacts, and regulatory enforcement activities.

Gleason, C. A., Jenkins, N. T., \& Johnson, W. B. (2008). The contagion effects of 85Accounting restatements. Accounting Review, 83(1), 83-110. https://doi.org/10.2308/accr.2008.83.1.83

Griffin, P. A., Grundfest, J. A., \& Perino, M. A. (2004). Stock price response to news of securities fraud litigation: An analysis of sequential and conditional information. Abacus, 4o(1), 21-48. https://doi.org/10.1111/j.14676281.2004.00149.X

Gupta, P. K., \& Gupta, S. (2015). Corporate frauds in India: Perceptions and emerging issues. Journal of Financial Crime, 22(1), 79-103. https://doi.org/10.1108/JFC-07-2013-0045

Karpoff, J. M., Lee, D. S., \& Martin, G. S. (20o8a). The cost to firms of cooking the books. Journal of Financial and Quantitative Analysis, 43(3), 581-611. https://doi.org/10.1017/So022109000004221

Karpoff, J. M., Scott Lee, D. S., \& Martin, G. S. (2008b). The consequences to managers for financial misrepresentation. Journal of Financial $\quad$ Economics, $\quad 88(2), \quad 193-215$. https://doi.org/10.1016/j.jfineco.2007.06.003

Khan, I. A. (2018). The effect of rating changes on stock returns: An empirical investigation. International Journal of Research in Management, Economics and Commerce, 8(3), 9-14.

Khan, I. A. (2011). Kaizen: The Japanese strategy for continuous improvement. International Journal of Business and Management Research, 1(3), 177-184.

Khan, I. A. (2012). An Overview of Insider Trading: US v/s. India. Journal of IMS Group, Listed in Cabell's Management Directory, USA, 9(1), 59-62.

Khan, I. A. (2010). Forensic accounting: A new paradigm for niche consulting. Proceedings of the National Conference on Contemporary Issues and Emerging Trends in Management and Technology ISBN : 978-81908869-3-2 (pp. 158-165).

Khan, I. A. (2018). Empirical evidence on dividends as a signal of firm value. VSRD International Journal of Business and Management Research, 8(1), 23-30.

Khan, I. A. (2021). Time-driven activity costing and its application in public hospitals. Management Accountant, 56(04), 89-93.

Kinney, W. R., \& McDaniel, L. S. (1989). Characteristics of firms correcting previously reported quarterly earnings. Journal of Accounting and Economics, 11(1), 71-93. https://doi.org/10.1016/0165-4101(89)90014-1

Koch, A. S. (2002). "Financial distress and the credibility of management earnings forecasts," GSIA Working Paper no. 2000-10. Carnegie Mellon University.

Lev, B., Ryan, S. G., \& Wu, M. (2008). Rewriting earnings history. Review of Accounting Studies, 13(4), 419-451. https://doi.org/10.1007/s11142-007-9041-4

Marquardt, C. A., \& Wiedman, C. I. (2004). The effect of earnings management on the 86Value relevance of accounting information. Journal of Business Finance and Accounting, 31(3) \& (4), 297-332.

Palmrose, Z.-V. (1999). Empirical research in auditor litigation: Considerations and data. American Accounting Association. 
Palmrose, Z.-V., Richardson, V. J., \& Scholz, S. (2004). Determinants of market reactions to restatement announcements. Journal of Accounting and Economics, 37(1), 59-89. https://doi.org/10.1016/j.jacceco.2003.06.003

Scholz, S. (2008). 'The Changing Nature and Consequences of Public Company Financial Restatements 19972006,' The Department of the Treasury.

Scholz, S. (2014). 'Financial Restatement Trends in the United States: 2003-2012,' Center for Audit quality.

Wu, M. (2002). "Earnings restatements: A capital market perspective," [PhD Thesis]. University of Michigan

$\mathrm{Xu}, \mathrm{T}$., Jin, J. J., \& Li, D. (2009). Long-term market reaction to earnings restatements. Academy of Accounting and Financial Studies Journal, 13.3, 45-65.87.

$\mathrm{Xu}, \mathrm{T}$., Najand, M., \& Ziegenfuss, D. (2006). Intra-industry effects of earnings restatements due to accounting irregularities. Journal of Business Finance and Accounting, 33(5-6), 696-714. https://doi.org/10.1111/j.14685957.2006.00607.x 